\title{
Article
}

\section{Is personalisation the right plan at the wrong time?: Re-thinking cash-for-care in an age of austerity}

Pearson, Charlotte and Ridley, Julie

Available at http://clok.uclan.ac.uk/13336/

Pearson, Charlotte and Ridley, Julie ORCID: 0000-0002-0879-308X (2016) Is personalisation the right plan at the wrong time?: Re-thinking cash-for-care in an age of austerity. Social Policy and Administration, 51 (7). pp. 1042-1059. ISSN 0144-5596

It is advisable to refer to the publisher's version if you intend to cite from the work. http://dx.doi.org/10.1111/spol.12216

For more information about UCLan's research in this area go to http://www.uclan.ac.uk/researchgroups/ and search for <name of research Group>.

For information about Research generally at UCLan please go to http://www.uclan.ac.uk/research/

All outputs in CLoK are protected by Intellectual Property Rights law, including Copyright law. Copyright, IPR and Moral Rights for the works on this site are retained by the individual authors and/or other copyright owners. Terms and conditions for use of this material are defined in the policies page.

\section{CLoK}

Central Lancashire online Knowledge www.clok.uclan.ac.uk

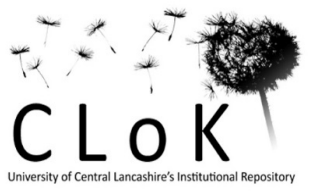




\title{
Is Personalization the Right Plan at the Wrong Time? Re-thinking Cash-for-Care in an Age of Austerity
}

\section{Charlotte Pearson ${ }^{a}$ and Julie Ridley ${ }^{b}$}

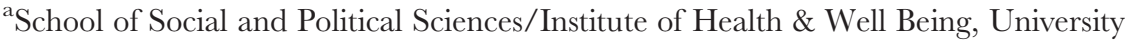 \\ of Glasgow, UK \\ ${ }^{\mathrm{b}}$ School of Social Work, Care and Community, University of Central Lancashire, UK
}

\begin{abstract}
As personalization has dominated the policy agenda for reform in social care, its roll-out as a mainstream option has coincided with global programmes of austerity which have targeted services for disabled people. Was this simply bad timing or was its implementation always part of the agenda for reform? Whilst the principle of cash-for-care schemes drew strongly on promoting the independence and autonomy of disabled people, early incarnations of direct payments policy in the UK were initially at least in part rolled out in light of potential cost savings to social care budgets. This article explores these and other issues in light of evaluations of the Scottish government's self-directed support (SDS) test sites (2009-II) and implementation of subsequent legislation enforcing models of SDS in Scotland from April 2OI4. Discussion draws on the authors' recent book (Pearson et al. 2OI4) to reflect on what the evidence can tell us about radically transforming social care at a time of global austerity.
\end{abstract}

\section{Keywords}

Personalization; Self-directed support; Austerity; Co-production; Scotland; Disability

\section{Introduction}

Over the past 20 years, personalization has emerged as a reforming concept across many areas of social policy in the UK (see Fox et al. 2013 for criminal justice; Pykett 2009 for education; Toerien et al. 2013 for employment; Forder and Jones 2OI4 for health), gaining what West (2OI3) identifies as an 'ideological grip' across the public sector. Its appearance in UK systems of social care draws in part from the legacy of disability activism culminating in a long fought campaign to secure direct payments as a facilitator of independent living (Campbell and Oliver I996; Morris I993), alongside a drive to 'modernize' and provide more cost-efficient and flexible modes of service provision in emerging local care markets (Pearson 2000; Spandler 2004). Accordingly, several commentators observe that personalization has come to stand for a number of competing and contradictory demands: perceived as either a

Author Emails: Charlotte.Pearson@glasgow.ac.uk; jridley1@uclan.ac.uk 
radical transformation of social care wherein the power balance shifts in favour of service users, or as an attempt to roll back the boundaries of the welfare state, to introduce neo-liberal ideals, and undermine public sector services and responsibilities (Needham and Glasby 20I4).

Elsewhere, European models of personalized social care have emerged with a similar diversity in policy discourse, varying from the rights-based scheme of Sweden, to more restrictive approaches - for example in Belgium, France and Germany - where policy set out specifically to reduce the numbers of persons entering residential care (Glasby 2013). Yet across the UK (Slasberg et al. 20I5), Europe (see Hauben et al. 20I2) and North America (Power 2OI4), the impact of austerity on personalized support in social care has been acute. Despite its roots in the independent living movement (Oliver and Sapey 2006), budget cuts and the broader reconfiguration of support for disabled people have acutely undermined these principles. The impact of austerity not only reflects a trend in disability activism, but one that has spread across services for other user groups. For example, Roy and Buchanan's (20I5) recent work shows how uncertainty and diminished budgets have greatly reduced investment in user activism through recovery services. Consequently, they argue that the parameters for providing services with social value, utility and effectiveness - the corner stones of independent living - have become far more limited. In recent years, commentators such as Taylor-Gooby and Stoker (2OII) have positioned the UK programme of austerity reforms as part of a broader restructuring of state services with a key goal to transfer responsibility from state to the private sector and ultimately to citizens. In these terms, others have identified personalization as the neo-liberal tool to facilitate this process across social care (Ferguson 2007; West 2013), signifying the end of collective services and community-based support.

Whilst Scotland has traditionally been slow to embrace the market in social care and was largely sceptical of previous policy incarnations of personalized support (see Pearson 2004), its implementation of new legislation for selfdirected support (SDS) undoubtedly takes social care into a new era. In this article, we explore the promotion of this new era for personalization in Scotland at a time of austerity. We begin by highlighting the challenges of the personalization agenda in a broader European context, as many models of personalized support have also been compromised by acute budgetary cuts. Discussion then moves to a commentary on Scotland's positioning of SDS in its early stages of implementation. This provides a more in-depth focus, by drawing on a series of findings from the evaluations of SDS test sites in three local authorities across Scotland (Ridley et al. 2OII, 2OI2; Pearson et al. 2OI4), information from the roll-out of SDS across Scotland (Scottish Government 20I3) and data from a Freedom of Information (FOI) request sent out to all 32 Scottish local authorities in April 2015. This asked authorities to indicate how many users, across different groups, were in receipt of each of the four SDS options. We consider whether the early roll-out of SDS offered a full range of personalization choices in Scotland. In doing this, we ask whether it is in fact the right plan for reform to facilitate independent living, but whose legitimacy has been weakened amidst the current spending restraints. Alternatively, was its role in the dismantling of local networks of community social care services, loss of community spaces and reducing access 
to personalized support an inevitable consequence of a neo-liberal agenda for welfare reform?

\section{Austerity and European Challenges to Personalized Support}

Before looking at changes in Scotland, we look briefly at how personalization policies have fared across Europe in response to the hostile economic climate. As the European Agency for Fundamental Rights warned in 20I2, the long-term impact of austerity changes clearly has serious implications for the well-being of a generation of disabled people and would progressively erode the advances that have been made in establishing and promoting the rights of disabled people (Hauben et al. 20I2). In the Agency's review of evidence of how austerity measures have impacted on the rights and status of disabled people, austerity has undoubtedly emerged as a negative influence, with significant differences over its impact on individual disabled people's lives observed across Europe. For example, countries such as Germany, Austria and Scandinavia appeared to have endorsed far fewer reductions in social benefits and social services, particularly in contrast to Greece, Ireland, Spain and Portugal. Like the UK, Hungary has tended to frame austerity measures through a broader programme of welfare reform and discourse of modernization. Yet overall, the pattern indicates a clear focus on the reduction of social services, thereby disproportionately impacting on disabled people (Pearson et al. 20I4).

As we detail later in this article, access to a personalized budget $(\mathrm{PB})$ has become increasingly restricted as the austerity cuts have taken hold. This is a trend that is also being replicated across Europe. Even in member states with well-established independent living schemes, key changes have been made which limit disabled people's access to personal assistance (PA). One of the tools used to restrict access has been through use of waiting lists. In Ireland, for example, waiting lists for social and health care have sharply increased and more than 25 per cent of persons with physical impairments are waiting for access to assessments for PA and support services (Hauben et al. 20I2). Similarly amongst Belgium's Flemish community, the PA waiting list has increased to 50,000 people - resulting in an estimated five to ten year wait for this type of support (Ratzka 20I2). In other countries such as Greece, where there are no $\mathrm{PB}$ schemes in place, financial support to enable disabled people to live more independently has simply been cancelled. Likewise in Portugal, plans to introduce PBs from $201 \mathrm{II}$ have been delayed indefinitely (Hauben et al. 20I2).

\section{Austerity, Personalization and a New Era for Social Care in Scotland}

Like many of the examples shown across Europe, for local authorities across the UK, rolling out of personalization and SDS in social care has also coincided with the economic crisis. In Scotland, the Social Care (Self Directed Support) Act 2013 was implemented from April 20I4, just as many of the austerity measures were beginning to take force. Leading up to this period, overall Scottish spending was reduced by around II per cent in real terms across a four-year period, leaving a 7 per cent cut in resources across local authority spending and 37 per cent in 
capital spending (Scottish Government 2OI2). As social care forms a core service within local authorities, cost cutting of local budgets has acute implications for its users. Whilst this had already had a significant impact on the planning and delivery of services (Main 2013), it was clear that changes were ongoing. Indeed, analysis by the Scottish Government indicated that the worst of the cuts were yet to emerge - with the full impact of changes expected in 20I6 (Scottish Government 20I4b). Furthermore, the election of a majority Conservative Government in May 2015 with a commitment to cut welfare spending by a further $\mathrm{E}_{\mathrm{I} 2} \mathrm{~b}$ billion signified a longer-term decline for funding in these service areas (Watt 20I5). As we show in this article, frontline social care workers in Scotland have continually expressed strong concerns about the current and future impact of austerity measures in adopting SDS. In order to examine these issues in more detail, we draw on findings from evaluative studies of SDS as the basis of a critical commentary on the positioning of policy in the early stages on implementation. The following section details the background and methodology to this work.

\section{Background to the Test Sites and Methodology}

In 2009, as government cuts on social welfare spending were starting to impact, the Scottish Government, Convention of Scottish Local Authorities and the Association of Directors of Social Work (ADSW) selected three local authorities to design and test out the systems needed to implement SDS in social care. The test sites were selected to represent a broad geographical spread including one remote rural site, and local authority performance based on Social Work Inspection Agency inspections. Each test site was given up to EI.2 million for just over two years (January 2009 to 3I March 2OII) to put in place systems that would facilitate a shift towards SDS. At the outset, the Scottish Government wanted the test sites to focus on three themes identified from research evidence as critical to enable this transformation: these were the need to reduce bureaucracy or 'red tape'; the importance of leadership and training; and the need for bridging finance to double fund existing services whilst introducing more individualized models of support.

The evaluative studies that we draw upon for this article used a mixed methods approach involving several elements. The first evaluation comprised a review of the literature on facilitators and barriers to SDS (Manthorpe et al. 2OII); gathered and collated quantitative information about those receiving SDS packages; conducted secondary analysis of national statistical data (Scottish Government 2OII); carried out interviews with national and local stakeholders; held action learning sets involving key stakeholders from each area; monitored test sites' implementation plans; and focused on 30 individual service users' and carers' experiences to better understand these new SDS systems from service users', family carers', and frontline workers' perspectives.

A follow-up evaluative study involved interviews with key stakeholders, a questionnaire survey of frontline staff and gathered systematic monitoring information to provide an update on developments in terms of the processes, practice, outputs and outcomes of SDS in the former test site areas (Ridley et al. 20I2). The views of over 60 different stakeholders from the three areas 
were analyzed, including service user organizations, advocacy services and voluntary sector providers. Over 500 frontline staff in adult social care across the three areas were surveyed via an online questionnaire (with a response rate of 43 per cent). This article draws in particular upon the findings from this survey to reflect upon frontline workers' experience and perceptions of the impact of budget cuts on SDS implementation.

In order to provide an updated snapshot of SDS implementation in Scotland, we also carried out a FOI request across the 32 local authorities in April 2015. Authorities were asked the question: What are the total numbers of users currently receiving SDS for each of the four options? At the time of writing, 29 local authorities had replied. Twenty-six of these offered full information on the questions asked, three only included partial data and two local authorities declined the request on grounds of cost. The implications of these findings are discussed later in this article.

Ethical and research governance approvals were received for the research from the University of Central Lancashire PsySoc Ethics Committee as well as from the ADSW and the three local authorities.

In this article, we consider findings across these studies alongside an FOI request to explore how the timing of the austerity cuts has impacted on the implementation of SDS. This is discussed through four key issues. First, by looking at the shift away from direct payments to SDS, we consider how grassroots disability activism and its considerable influence in the development of direct payments became diluted under the infiltration of neo-liberalism and the personalization of social care. Second, discussion moves to examine these ideas more specifically in the Scottish context by looking at how personalization has been adopted through new legislation and what we define as an 'evolving concept of SDS'. Third, we return to issues relating to the discourse of cost-efficiency associated first with direct payments and then with the broader personalization agenda. This has clearly been a significant theme in the adoption of personalization policies across the UK - particularly when comparing to other countries such as Norway. Indeed, we show how findings from the test sites offer some evidence to support this contention, whereby in some areas, SDS has been used as a mechanism to cut support packages. This links into the final area, a focus on the limitations and problems of the resource allocation system (RAS).

\section{From Direct Payments to Self-directed Support}

As has been documented extensively elsewhere (e.g. Campbell and Oliver I996; Glasby and Littlechild 2009) the idea of cash-for-care as an alternative to directly provided services originated in the I970s in the USA (Arksey and Kemp 2008). This saw a small group of students with physical impairments at the University of Berkeley secure payment of cash in place of services to buy-in support which fitted their daily needs. Gradually, news of this spread throughout the USA and by the I980s, similar challenges were being made by groups of disabled people in the UK. Throughout the I980s and I990s, indirect payments - those administered through third parties such as voluntary organizations - were used to overcome legal restrictions to a cash-based model 
of support across the UK. In line with actions a few years earlier in the USA, the roles of small groups of disabled people were central to changes during this time. They demanded a more flexible alternative to rigid and paternalistic modes of service provision offered to them by local authorities. In Scotland, although developments were more limited, pockets of activism also emerged during the I980s, notably in the former Lothian region. At this time, Lothian Regional Council permitted three indirect payments to be made. While this was initially approved, problems arose when, in 1995, the then Department of Social Security was alerted to this practice and suspended all the payments of those involved. A challenge to the case in Lothian was made and won by the local authority, but the case had raised the profile and potential of cash payments to increase disabled people's choice and control over their social care, thereby instigating the need for a formal legislative path to be developed (Pearson 2004). Disability activism therefore undoubtedly played an important role in moving towards legislation for direct payments in the late I990s, although as we discuss shortly, a discourse of cost-efficiency always prevailed.

Whilst many welcomed the shift to direct payments, change was not uniformly embraced with strong resistance emerging in many parts of the UK. In particular, the number of users in Scotland, Wales and Northern Ireland were especially low (Riddell et al. 2005) when compared with key local authorities in the south of England such as Hampshire and Essex. From 1997 to 2003, various attempts were made by the then Scottish Executive and Westminster Governments to reignite policy, but uptake was never more than marginal (Priestley et al. 20IO).

Under the Labour Government (I997-20IO) many of the themes which linked direct payments to the Conservatives' broader agenda of marketization were developed through a focus on the personalization of social care services (Pearson 2004). At this stage, ideas promoted by Leadbeater (2004; Leadbeater et al. 2008) exploring how services could be modernized through the direct participation of users in service delivery, had a profound influence on reforming the adult social care system. Leadbeater et al. (2008: 47) argued strongly in favour of a model of consumerism which encouraged users to take on the role of a budget holder, but at the same time embracing themes of citizenship and related notions of rights and entitlements. Although widely popular amongst Westminster Government circles from the mid-2000s, caution was expressed from a number of quarters.

For many, the promotion of consumerist identities sat uncomfortably with the experiences and identities of many people who use social care and mental health services (Carr 2OII; Morris 2004). Others such as Ferguson (20I2) and Dodd (2013) argue that the social justice values associated with personalization policies and which were so strongly promoted by the disability movement, have been subsumed by neo-liberalism. Therefore rather than extend individual autonomy, Ferguson warned that such policies would be used by cash-strapped local authorities to make savings from their services. As we discuss shortly, it is clear that this neo-liberal discourse has remained dominant in the roll-out of personalization and is an unhelpful legacy for its implementation (Pearson et al. 20I4).

In Scotland, the shift to a more personalized system of social care has been slower and more complex (Kettle et al. 2OII). As stated, this undoubtedly 
reflected a less enthusiastic drive towards the marketization of social care than south of the border and a reluctance in many areas to fully embrace direct payments (Pearson 2004). As policy emerged, the Scottish Government employed the term Self Directed Support (SDS) to develop distinctive policy goals (Manthorpe et al. 20I4), setting out SDS to be part of its aspirations to create a 'healthier nation with stronger and safer communities' (Scottish Government 2007: 2).

It is clear from the history of direct payments, personalization, individual budgets (IBs), SDS and other cash-for-care based schemes in social care that terms can be used interchangeably and are confusing (Manthorpe et al. 20I4). Notably, direct payments and personal budgets have often been set out as being essentially the same thing - in that they both involve a cash alternative to directly provided services. However, as Beresford (2009) notes, there are important differences in their underpinning ideologies. As discussed earlier, direct payments were a grassroots development emerging from the disabled people's movement and a desire to equalize opportunities and increase independent living (see Glasby and Littlechild 2009), whilst personal budgets evolved from developments largely driven by professionals critical of the welfare state and its ability to promote independent living. Direct payments are based on a social model of disability and the philosophy of independent living, whereas 'personalization' emerged from the vision of welfare reformers such as In Control - pioneers of SDS and IBs in 2003 - as an approach to enable disabled people to direct and take charge of their support and which has since underpinned UK-wide policies promoting personalization (Pearson et al. 2OI4). The following section explores this in relation to the development of SDS in Scotland.

\section{Self-directed Support - An Evolving Concept}

The Social Care (Self-directed Support) (Scotland) Act 20I3 (the SDS Act) offered four different options for SDS. These included option I, a direct payment approach; option 2, a selection of support by the user but arranged through the local authority or other agency on their behalf; option 3, support organized and provided by the local authority; or option 4, a mixture of these options (Scottish Government 2OI4a). Critically, support for SDS from the governing Scottish National Party brought policy into the mainstream of social care provision and thereby increased the numbers of people directing their own support from the time of implementation in April 2OI4. Unlike previous policy incarnations, the focus on direct payments as only one variant of the SDS approach has caused some confusion with SDS becoming an 'evolving' or 'elastic' concept, which has been variously defined and implemented much as has personalization (Ridley et al. 2OII; Manthorpe et al. 2OII; Larsen et al. 20I3). As discussion moves to look at some of the broader policy discourses, we re-visit this theme later in the article.

Commentators identify a perceptible shift in the rhetoric around personalization, moving from a primary focus on individual control over budgets, to an emphasis on the importance of offering 'choice and control' and focusing on individual outcomes (Beresford 2009). The experience of the test sites 
indicates a similar evolution of the concept of SDS in Scotland. Early on, the stated purpose of the test sites had been to increase the number and range of people receiving direct payments, "The very baseline is Manifesto commitments, each of the test sites must demonstrate increase in take-up of direct payments as an absolute ...' (Interview with national policymakers in 20IO, quoted in Pearson et al. 2OI4: 3I-2).

In contrast, local and national stakeholders insisted that SDS was a broader concept implementing 'personalized services', and that it consisted of a spectrum of options that included direct payments at one end and local authority-provided services at the other. This broader definition of SDS was also in evidence in the National Strategy for SDS (Scottish Government 20IO), as well as in the subsequent SDS Act. Furthermore, the range of support packages evidenced during, and a year after the test sites, reflected this. Initially at least, direct payments (option I) was the most common SDS option (Ridley et al. 2OII), while at the follow up evaluation, the majority of SDS packages were arranged and managed by local authorities (option 3) (Ridley et al. 2OI2): a pattern mirroring the experience of PBs in England, the majority of which were taken in the form of local authority managed budgets (ADASS 2OII; Beresford 2013; Slasberg et al. 20I3). Indeed, by the time of our FOI request in April 2OI5, 73 per cent of the local authorities that responded $(n=26)$ indicated that option 3 -support organized and provided by the local authority - was the most commonly used form of SDS. In only one local authority did direct payment recipients (option I) outnumber those in option 3 .

\section{A Discourse of Cost-efficiency}

Since legislation implementing direct payments in the late I990s, and the promotion of personalization by Leadbeater et al. (2008), a discourse of cost-efficiency has been a major feature of policy promotion across the UK. Even before this time, the successive dismissals of direct payment legislation on the statute throughout the I990s were only brought to an end when the British Council of Disabled People commissioned research, which in promoting the merits of direct payments also showed them to be up to 40 per cent cheaper than directly provided services (Zarb and Nadash I994). Whilst this has never been realized in practice, the link between personalization and costefficiency has remained a dominant theme in the UK. Leadbeater et al. (2008) and others (see Duffy 20IO; Needham 2OII a, 2OII b) have highlighted the link, suggesting that savings could even be as high as 45 per cent. This despite the national Individual Budget (IBSEN) study (Glendinning et al. 2008) finding an II per cent increase in infrastructure costs, thus contradicting the claim that the process could increase value for money.

It is therefore clear that the focus on budgets and empowerment through cashfor-care has been a key feature of personalization in the UK. This is reiterated by Christensen and Pilling (2OI4), who examined the differences between personalization policies implemented in social democratic welfare regimes and those in more neo-liberal contexts. In looking at this issue, they provide a comparative analysis of Norway and England and argued that whilst both ran systems that had been supported by active disability movements and promoted market based 
models for social care provision, the main difference lies in their promotion of care markets and the focus on consumer roles. In England a key policy emphasis has been to give users knowledge of the amount they have to spend (indicative budget) on their support upfront and to have choice and control on how this is spent (Glasby and Duffy 2007).

Thus the speed at which IBs have been implemented in the UK was, as Carr (2013) has observed, made on the basis of scant evidence. In Scotland, the results of a small-scale IB demonstration project in North Lanarkshire were positive about the benefits and the potential of the In Control approach (Etherington et al. 2009), and this was followed by test sites adopting a similar approach in 2009 (Ridley et al. 20II). The nexus of control promoted at the heart of the personalization strategy in England has often been presented as entirely positive and that if people have choice and control simply by virtue of knowing the allocated budget, its actual size is unimportant. As Slasberg et al. (2OI2, 2OI3, 2OI5) observe, however, this fails to acknowledge that positive results were associated with $\mathrm{PBs}$ being taken as direct payments, and further that those receiving local authority managed services did not experience the same positive outcomes. Furthermore, better individual outcomes have been found for those using a direct payment to employ PAs and have enough resource to meet social and leisure needs (Slasberg et al. 2OI5). By contrast, Norway's focus has been on the control (or what Christensen and Pilling [2OI4] term 'citizen choices') they have over the actual support received, that is, the role of managing their support workers.

The experience of the test sites offers a different insight regarding upfront allocations. While not disputing that a resource allocation in the form of an IB should be transparent, the Dumfries \& Galloway test site concluded that such transparency sometimes resulted in inferior solutions as it shifted the focus to the budget entitlement instead of on the outcomes sought. Instead, it concluded that prior to introducing a budget figure, identifying and working with natural support networks led to the development of more creative solutions based on individuals' assets and community resources:

\section{'The In Control 7-steps didn't work for us. It was the money upfront bit. What we learnt from the test site was that if you tell people what the money is you get a plan that is that to the penny. We did a few where we didn't say what the indicative budget was and quite a few came in at less and they were more outcomes focused. Giving the figure upfront we found was skewing people's thinking, and the plans were not quite as creative' (Local authority implementation staff, quoted in Pearson et al. 20I4:35)}

As other research has shown (Hatton and Waters 2013), user and carer satisfaction with SDS has been linked with agreement about the panel's decision on the size of the IB in relation to what they identified was needed (Ridley et al. 2OII). User and carer dissatisfaction in the test sites was commonly associated with there being some discrepancy between what they perceived as their needs and the final financial allocation decided by the local authority, as well as with differences between users, carers and professionals in their perceptions of need. Some users felt they had been encouraged to have 'false expectations' as one disabled man in his 70 s demonstrates: 
'They (social workers) took everything into consideration that we were telling them and they wrote it down and then they checked it against what we had written down, the form we had filled in, and they seemed quite in agreement with what we needed and what we had self-assessed and then as I say it went away and sat in front of this Board (panel) for a year and when we got word back, everything had been cut, we only needed so many hours and ... in the morning and so many hours at night for getting ready for bed and whatever ...' (quoted in Ridley et al. 2OII: 57)

Frontline workers from the Glasgow test site in particular linked SDS with making cuts in social care budgets, identifying negative impacts on service users' choice and control. Personalization they said, was a 'means to cut services', a 'guise to reduce budgets', and the process was overtly 'budget orientated' rather than driven by an ethos of independent living. The direct impact of cuts on social care and the inability then to implement SDS in the way intended, was a common theme, even though many typically prefaced their comments with 'personalization is a good idea but ...'. Some highlighted increased stress for service users and carers with many experiencing a reduction in traditional packages of care when they were moved onto SDS, which impacted negatively on their quality of life. The majority of frontline respondents made this clear link:

\begin{abstract}
'The SDS process is being used as a mechanism for managing budgets. However this is in relation to the overall financial climate and the cuts would have been required regardless of the implementation of SDS ... Support packages tend to only deal with basic need and no longer take into consideration quality of life and in some cases the panel does not account for carers' stress within the support package.' (frontline worker responding to the online survey 20I2)
\end{abstract}

It is likely that such dissatisfaction with SDS budgets will continue to increase in the future, given the financial constraints that local authorities will increasingly face (see Scottish Government 2OI4b).

\title{
Limitations of Resource Allocation Systems
}

One of the most controversial elements of the personalization programme in social care has been the system for allocating resources or RAS (Slasberg et al. 2OI2; Series 2OI4). The RAS is defined as 'a set of rules that can be used to calculate an individual budget' (Duffy 20I0: 206). It has therefore been central in how local authorities make decisions about individual packages. Yet growing evidence suggests that RAS are operating in ways that were not anticipated by those who promoted them (Series 2OI4). Indicating the strength of feeling evoked by RAS, a user-led organization consulted during the test sites evaluation observed, 'we [disabled people's movement] fought for SDS and personalisation but not for the RAS' (Pearson et al. 20I4: 36). All three test sites struggled with setting up RAS under the In Control model, and had not resolved these issues one year on. A major limitation to RAS was found in applying it across client groups: 
'Getting the resource allocation right is an art not a system - it needs to be flexible. Slotting people into boxes is not going to work. At the end of the test site and now there is still a need to develop an equitable way of distributing and managing resources. We know what we have is not quite right but we haven't solved this issue yet.' (local authority implementation staff, Pearson et al. 20I4: 59)

Dissatisfaction with RAS has tended to centre around increased bureaucracy and questions have been raised as to what constitutes a 'fair allocation' (Slasberg et al. 2013). As West (2013) found in her study of personalization in an English authority, amid austerity cuts of around 30 per cent, resource restrictions meant that for many, the very possibility of obtaining a PB was denied. Yet rather than address these issues directly, the Council moved forward with the scheme and presented it as part of a 'transformation strategy' which would help widen the social care market and drive out perceived inefficiencies in service provision. West's work highlighted how populations of social care users have been left outside new systems of personalized support by reframing the boundaries of eligibility. In Scotland, similar patterns are beginning to emerge. For example in Glasgow, the initial development of SDS coincided with an II per cent cut from the $f 89$ million social care budget during 2OI2 /I3 (Main 2OI3). In explaining the cuts, the local authority has presented personalization as a strategy for services to be delivered more efficiently. It will be interesting whether defining eligibility determination using national eligibility criteria as under the Care Act 2OI4 in England, will alter this picture south of the border (Care and Support (Eligibility Criteria) Regulations 2OI4).

Research finds a major discrepancy overall between indicative and final budget figures agreed by RAS panels (Series and Clements 2013; Slasberg et al. 20I3). This was borne out to some degree by the experience of the Scottish test sites, though our data is derived from small participant numbers and is not strictly comparative with these other studies. Nonetheless, our data indicates the emergence of similar concerns in Scotland, with only a minority of frontline workers suggesting that outcomes from SDS were more positive:

'We are clearly advised to work towards less rather than more and we know before we discuss cases that the budget needs to come in less than the estimated budget and definitely less than existing service provision unless there is compelling reasons to argue differently...' (frontline worker responding to online survey, 20I2)

One year on from the test sites, frontline workers from Glasgow commented that final budget levels were invariably lower than those proposed, and that service users were experiencing cuts in support. Around three out of five agreed that SDS budgets were insufficient to meet needs, which was similar to the findings of the UK-wide Community Care and Unison PB Survey (in 2OII), showing 48 per cent of social work practitioners assessing PBs as insufficient to meet service users' needs (Community Care and Unison 2OII). Whilst the strength of feeling linking SDS with cuts was less pronounced in two of the test sites, frontline workers in Highland expressed disquiet that budget constraints made it difficult to get funding approval for more 'aspirational' rather than 'critical' needs, indicating a shift in the 
operation of eligibility criteria. Such findings strike as ironic given personalization was initially promoted as 'aspirational' (Needham 20IIb).

\section{Discussion and Conclusions}

As Scotland has moved to implement SDS as the mainstream framework for social care, this article has raised a number of concerns relating to the timing and underpinning discourses influencing this shift. Findings from SDS test sites in Scotland and more recent figures on SDS take-up from local authorities indicate that SDS has moved away from direct payments to a focus on support which is organized and managed by the local authority. At best, those who have entered the SDS system in Scotland may have experienced greater involvement in the discussion about their needs and support packages. However, as test site results show, there is also evidence that reassessment through a new SDS process falls short of co-production and may, at worst, amount to reduced support packages. Those implementing SDS continue to face a number of thorny issues not least with systems of allocating resources which tend to become heavily bureaucratized and act as mechanisms for delivering cuts (Beresford 20I3). As Stack (20I3) observes, the reality of RAS is 'more opaque' than intended. The root of the problem may however lie more fundamentally as Slasberg et al. (2013) argue in what is meant by 'fair allocation'.

Furthermore, as Hall (2OII) argues, the new 'care market place' for personalization has both transformed existing relations of care and constrained collective and interdependent forms of care that many people value, resulting in a 'lack of fit' between the needs of different groups of disabled people and personalized care provision. As local authorities devolve their budgets to the individual, collective forms of support will inevitably receive less resourcing (Needham 20I3). The implications of more privatized experiences of social care support and reduced opportunity for social interaction linking with broader critiques of neo-liberalism across the social sciences (Dodd 20I3; Verhaeghe 20I4). As Monbiot (2OI4) suggests, 'the market was meant to emancipate us, offering autonomy and freedom. Instead it has delivered atomization and loneliness'.

Whilst the cuts from local authority budgets have undoubtedly impacted on the roll-out of SDS, the establishment of the Scottish Independent Living Fund (SILF) in July 2OI5 - with a $£ 5.5$ million investment from the Scottish Government to continue with existing payments - represents an important departure from policy in England and Wales (Northern Ireland is also covered by the SILF). Since its inception in the mid-I990s, the Independent Living Fund (ILF) allowed an alternative route to cash payments for disabled people with the highest support needs, as funds were paid via a charity and funded through central government rather than local authorities. It proved highly popular with its users and played an important role in the evolution of personalized support (Morris 2004). However, the UK coalition Government (2OIO-I5) set in place a decision to close the ILF in July 2015 and transfer monies to local authorities in England and Wales without a requirement for them to be ring-fenced - a move that has been widely criticized, and raised questions about how already cash-strapped authorities would cover the fund's costs and enable its users to sustain the same levels of independence (White 2013). The contrast 
in responses to dealing with the future of the ILF north and south of the border are therefore important when looking at the broader personalization agenda, as each has very different implications for the goals of autonomy, citizenship and control.

Despite growing critiques of personalization, Beresford (2OI4) argues that innovative grassroots developments have much to offer. Notably, initiatives such as those led by The Standards We Expect consortium (Joseph Rowntree Foundation 2OII) have set out a vision for person-centred support and developing 'bottom-up' ways of challenging barriers to this. Although highlighting the difficulties in achieving personalized outcomes in a hostile economic climate, these commentators also argue that the funding shortfall is intrinsically linked to the continued existence of a social care culture that remains at odds with person-centred support and the principle of self-determination. The solution, argue Slasberg and Beresford (2OI5), lies in learning the 'right lessons' from the implementation of personalization so far, moving from consumerist notions of individual control and a preoccupation with $\mathrm{PBs}$, to refocusing on truly personalized support plans built from accurate assessment of needs, sufficiency of resource and flexibility of provision.

In Scotland, examples of positive practice in SDS are emerging. Research funded by Glasgow Disability Alliance (Witcher 2OI4) was set up by a userled organization to explore options for disabled people to enable increased choice and control in their day-to-day lives. The project focused on the core requirements of facilitating individual choice and independent living, and found there was no obvious or consistent relationship between the amount of money that was spent on realizing individual choices and the scale of its impact. For example, some packages involved considerable investment for a British Sign Language interpreter to be available, whereas others required only a few hundred pounds for transport costs so that the individual could attend classes of his or her choice. Similarly, the test sites found no correlation between the size of the support package and the impact of SDS on individuals' and families' lives (Ridley et al. 2OII). As Witcher (2OI4), along with Slasberg and Beresford (2OI5) argue, the success of SDS is in support that is truly person-centred and is clearly linked to self-defined outcomes. As such, the message of increased and more meaningful user-control from this type of initiative, underlines how control - or in the Norwegian concept of 'citizen choices' (Christensen and Pilling 2OI4) should be a more central preoccupation in the implementation of SDS.

This links in with broader critiques by Beresford (20I4), who argues that in England, commissioning authorities must ensure that the price paid in the 'care market' for services is enough to provide a personalized approach. In doing this, he emphasized the need for local areas to develop a network of providers who are able to deliver flexible and responsive services and not simply block contracts. Although the marketization of social care is arguably at a more advanced stage in England, Scotland still has lessons to learn and securing a key role for user-led organizations would be an important way forward. In Norway, users are increasingly choosing a user-led organization 'Uloba' as their service provider for PA. As Christensen and Pilling (20I4) show, these users are found to be significantly more satisfied with this model of support than those who have chosen the municipality as the employer. 
However, the promotion of this type of user-led model across the UK raises a note of caution in light of the wider challenges to sustaining activism as part of service provision and policy development amid long-term cuts to budgets. For Roy and Buchanan (20I5), the climate of insecurity and uncertainty emanating from austerity has the potential to erode solidarity and trust, with the threat of unemployment making opportunities for service commissioners and providers to develop activism particularly difficult. Evidence from the initiatives documented by Beresford and Witcher above, as well as Roy and Buchanan's own observations in recovery services, show that this more negative outcome is not inevitable, but the austerity environment is undoubtedly more hostile to this vital support infrastructure.

In conclusion, at one level SDS is an uncomplicated idea that is impossible to disagree with, but as the experience of implementing SDS policy in Scotland has shown, there are ongoing challenges that need to be faced. To implement SDS in any meaningful way requires a major paradigm shift in the relationship between users and professionals, and a refocus on the importance of the ethos of independent living. Further, the will to promote user-centred practice and to embrace transformational change cannot be progressed in isolation from the austerity drive that is evident across Europe.

\section{Acknowledgements}

We are indebted to the service users and carers as well as frontline practitioners and other professionals who shared their experiences and perspectives of the SDS test sites with us, and to the Scottish Government which commissioned the research studies. This article builds on the work of the original project team involving Dr Helen Spandler, Dr Ann Rosengard, Susan Hunter, Simon Little, Professor Jill Manthorpe, Dr Michelle Cornes, Bill Gray, Dr Tony Kinder and Angela Menhennet.

\section{References}

Arksey, H. and Kemp, P. A. (2008), Dimensions of Choice: A Narrative Review of Cash-for-care Schemes, York: University of York, Social Policy Research Unit.

Association of Directors of Adult Social Services (ADASS) (2OII) ADASS Report on Personalisation Survey, ADASS, http://www.adass.org.uk/uploadedFiles/adass_content/ publications/policy_documents/key_documents/ADASS\%20report \% 20personalisa tion \% 20survey\% 205.pdf (accessed 20 May 20I5).

Beresford, P. (2009), Whose Personalisation? Think Pieces No. 47, March, London: Compass.

Beresford, P. (ed) (2013), Personalisation, Bristol: Policy Press (available as e-book).

Beresford, P. (20I4), Hampshire competition paves the way for innovative approaches to home care, The Guardian, I9 February, http://www.theguardian.com/social-carenetwork/20I4/feb/I9/user-led-innovative-approaches-to-home-care (accessed 26 March 2OI4)

Campbell, J. and Oliver, M. (I996), Disability Politics: Understanding our Past, Changing our Future, London: Routledge.

Carr, S. (2OII), Enabling risk and ensuring safety: Self-directed support and personal budgets, Fournal of Adult Protection, I3, 3: I22-36. 
Carr, S. (2013), Personalisation, participation and policy constitution: A critique of influences and understandings. In P. Beresford (ed) Personalisation, Bristol: Policy Press (available as e-book).

Christensen, K. and Pilling, D. (20I4), Policies of personalisation in Norway and England: On the impact of political context, Foumal of Social Policy, 43, 3: 479-96.

Community Care and Unison (2OII), Personalisation Survey, http://www. thinklocalactpersonal.org.uk/News/PersonalisationNewsItem/?cid=8966 (accessed 4 August 20I4).

Dodd, S. (20I3), Personalisation, individualism and the politics of disablement, Disability and Society, 28, 2: 260-73.

Duffy, S. (20IO), Future of Personalisation, Sheffield: Centre for Welfare Reform.

Etherington, K., Hatton, C. and Waters, J. (2009), Way Ahead. Our Early Experience in North Lanarkshire of Demonstrating the Impact of the In Control Approach, Edinburgh: In Control Scotland.

Ferguson, I. (2007), Increasing user choice or privatizing risk?: The antinomies of personalisation, British Journal of Social Work, 37, 3: 387-403.

Ferguson, I. (2012), Personalisation, social justice and social work: A reply to Simon Duffy, Fournal of Social Work Practice, 26, I: 55-73.

Forder, J. and Jones, K. (2OI4), Evaluation of the personal health budget pilot programme. In C. Needham and J. Glasby (eds) Debates in Personalisation, Bristol: Policy Press.

Fox, A., Fox, C. and Marsh, C. (2OI3), Could personalisation reduce re-offending? Reflections on potential lessons from British Social Care Reform for the British Criminal Justice System, fournal of Social Policy, 42, 4: 72I-4I.

Glasby, J. (20I3), Personal budgets let patients care for themselves, The Conversation, 25 November, http://theconversation.com/personal-budgets-let-patients-carefor-themselves-206I8 (accessed 20 May 20I5).

Glasby, J. and Duffy, S. (2007), Our Health, Our Say - What Could the NHS Learn from Individual Budgets and Direct Payments? Birmingham: Health Services Management Centre, University of Birmingham and In Control.

Glasby, J. and Littlechild, R. (2009), Direct Payments and Personal Budgets: Putting Personalisation into Practice, Bristol: Policy Press.

Glendinning, C., Challis, D., Fernandez, J., Jacobs, S., Jones, K., Knapp, M., Manthorpe, J., Moran, N., Netten, A., Stevens, M. and Wilberforce, M. (2008), Evaluation of the Individual Budgets Pilot Programme: Final Report, York: Social Policy Research Unit, University of York.

Hall, E. (2OII), Shopping for support: Personalisation and the new spaces and relations of commodified care for people with learning disabilities, Social and Cultural Geography, I2, 6: 589-603.

Hatton, C. and Waters, J. (2OI3), The Second (POET): Survey of Personal Budget Holders and Carers, London: In Control Publications.

Hauben, H., Coucheir, M., Spooren, J., McAnaney, D. and Delfosse, C. (2012), Assessing the impact of European governments' austerity plans on the rights of people with disabilities, http://www.enil.eu/wp-content/uploads/2OI2/I2 /Austerity-European-Report_FINAL.pdf (accessed 29 April 20I5).

Joseph Rowntree Foundation (2OII), Sustaining Social Care: Transforming Social Support, York, Joseph Rowntree Foundation, http://www.jrf.org.uk/sites/files/ jrf/social-care-personal-support-summary.pdf (accessed 29 April 2015).

Kettle, M., O'Donnell, J. and Newman, S. (2OII), Getting together and being personal: Building personalisation on a co-production approach, fournal of Care Services Management, 5, I: $29-34$.

Larsen, J., Ainsworth, E., Harrop, C., Patterson, S., Hamilton, S., Szmczynska, P., Tew, J., Manthorpe, J. and Pinfold, V. (20I3), Implementing personalisation for 
people with mental health problems: A comparative case study of four local authorities in England, Foumal of Mental Health, 22, 2: I74-82.

Leadbeater, C. (2004), Personalisation through Participation: A New Script for Public Services, London: Demos.

Leadbeater, C., Bartlett, J. and Gallagher, N. (2008), Making it Personal, London: Demos.

Main, J. (20I3), Personalisation - Plus ca change? In P. Beresford (ed) Personalisation, Bristol: Policy Press (available as e-book).

Manthorpe, J., Hindes, J., Martineau, S., Cornes, M., Ridley, J. Spandler, H., Rosengard, A., Hunter, S., Little, S. and Gray, B. (2OII), Self-Directed Support: A Review of the Barriers and Facilitators, http://www.scotland.gov.uk/Publications/ 20II/03/3009I835/o (accessed 29 January 20I4).

Manthorpe, J., Martineau, S., Ridley, J., Cornes, M., Rosengard, A. and Hunter, S. (20I4), Embarking on self-directed support in Scotland: A focused scoping review of the literature, European Fournal of Social Work, I8, I: 36-50.

Monbiot, G. (2OI4), Sick of this market-driven world? You should be, The Guardian, 5 August, http://www.theguardian.com/commentisfree/20I4/aug/o5/neoliberalismmental-health-rich-poverty-economy (accessed 20 May 20I5).

Morris, J. (I993), Independent Lives: Community Care and Disabled People, Basingstoke: Macmillan.

Morris, J. (2004), Independent living and community care: a disempowering framework, Disability and Society, I9, 5: 427-42.

Needham, C. (20IIa), Personalisation: From story-line to practice, Social Policy $\mathbb{E}^{\circ}$ Administration, 45, I: 54-68.

Needham, C. (20II b), Personalising Public Services. Understanding the Personalisation Narrative, Bristol: Policy Press.

Needham, C. (2013), Personalisation: From day centres to community hubs, Critical Social Policy, 34, I: 90-Io8.

Needham, C. and Glasby, J. (eds) (20I4), Debates in Personalisation, Bristol: Policy Press.

Oliver, M. and Sapey, B. (2006), Social Work with Disabled People, Basingstoke: Palgrave Macmillan.

Pearson, C. (2000), Money Talks? Competing discourses in the implementation of direct payments, Critical Social Policy, 20, 4: 459-77.

Pearson, C. (2004), Keeping the cash under control: What's the problem with direct payments in Scotland? Disability and Society, I9, I: 3-I4.

Pearson, C., Ridley, J. and Hunter, S. (20I4), Self-directed Support: Personalisation, Choice and Control, Edinburgh: Dunedin Academic Press.

Priestley, M., Riddell, S., Jolly, D., Pearson, C., Williams, V., Barnes, C. and Mercer, G. (2OIO), Cultures of welfare at the front line: Implementing direct payments for disabled people in the UK, Policy and Politics, 38, 2: 307-24.

Power, A. (2OI4), Personalisation and austerity in the crosshairs: Government perspectives on the remaking of adult social care, Fournal of Social Policy, I, I8: 829-46.

Pykett, J. (2009), Personalisation and de-schooling: Uncommon trajectories in contemporary education policy, Critical Social Policy, 29, 3: 374-97.

Ratzka, A. (20I2), Personal assistance and the crisis: Now is the time to promote direct payments for personal assistance, http://www.independentliving.org/node/II95 (accessed 27 March 20I4).

Riddell, S., Pearson, C., Barnes, C., Jolly, D., Mercer, G. and Priestley, M. (2005), The development of direct payments in the UK: Implications for social justice, Social Policy and Society, 4, I: 75-85.

Ridley, J., Spandler, H., Rosengard, A., Little, S., Cornes, M., Manthorpe, J., Hunter, S., Kinder, T. and Gray, B. (2OII), Evaluation of Self-Directed Support Test Sites in Scotland, Edinburgh: Scottish Government Social Research. 
Ridley, J., Spandler, H., Rosengard, A. with Menhennet, A. (20I2), Follow-Up Evaluation of Self-Directed Support Test Sites in Scotland, Edinburgh: Scottish Government Social Research.

Roy, A. and Buchanan, J. (20I5), The Paradoxes of Recovery Policy: Exploring the Impact of Austerity and Responsibilisation for the Citizenship Claims of People with Drug Problems, Social Policy \& Administration, doi: IO.IIII /spol.I2I39.

Series, L. (2OI4), Resource allocation systems: Complex and counterproductive? In C. Needham and J. Glasby (eds), Debates in Personalisation, Bristol: Policy Press.

Series, L. and Clements, L. (2013), Putting the cart before the horse: Resource allocation systems and community care, Joumal of Social Welfare and Family Law, 35, 2: 207-26.

Scottish Government (2007), Better health, better care: Action plan, http://www. scotland.gov.uk/Resource/Doc/206458/005487I.pdf (accessed 3 April 20I4).

Scottish Government (20IO), Self-directed Support: A National Strategy for Scotland, http://www.scotland.gov.uk/Publications/20IO/O2/05I33942/O (accessed 27 February 20I4).

Scottish Government (20II), SDS (Direct Payments) Statistics, Statistic Division http:// www.gov.scot/Resource/Doc/359028/OI2I3I4.pdf (accessed I4 May 20I5).

Scottish Government (2OI2), Scotland's spending plans and draft budget 2OI2-I3, http://www.scotland.gov.uk/Topics/Government/Finance/I8I27 (accessed 3I March 2OI4).

Scottish Government (2013), Social Care (Self-directed Support) (Scotland) Act 20I3, http://www.legislation.gov.uk/asp/2OI3/I/contents/enacted (accessed I4 May 20I5).

Scottish Government (20I4a), Statutory Guidance to Accompany the Social Care (Self-directed Support) (Scotland) Act 2013, Edinburgh: Scottish Government.

Scottish Government (20I4b), UK Government Cuts to welfare spending in Scotland Budget 2OI4, http://www.scotland.gov.uk/Topics/People/welfarereform/analysis/ ukgwelfarecutsbudg20I4 (accessed 29 April 20I5).

Slasberg, C. and Beresford, P. (2OI5), Building on the original strengths of direct payments to create a better future for social care, Disability \& Society, doi: IO.IO80/ 09687599.2015.I007672.

Slasberg, C., Beresford, P. and Schofield, P. (20I2), Can personal budgets really deliver better outcomes for all at no cost? Disability \& Society, 27, 7: 1029-34.

Slasberg, C., Beresford, P. and Schofield, P. (2013), The increasing evidence of how SDS is failing to deliver personal budgets and personalisation, Research, Policy and Planning, 30, 2: 9I-IO5.

Slasberg, C., Beresford, P. and Schofield, P. (2OI5), Further lessons from the continuing failure of the national strategy to deliver personal budgets and personalisation, Research, Policy and Planning, 3I, I: 43-53.

Spandler, H. (2004), Friend or foe? Towards a critical reassessment of direct payments, Critical Social Policy, 24, 2: 187-209.

Stack, P. (20I3), The need for true person-centred support. In P. Beresford (ed), Personalisation, Bristol: Policy Press (available as e-book).

Taylor-Gooby, P. and Stoker, G. (2OII), The coalition programme: A new vision for Britain or politics as usual? Political Quarterly, 82, I: 4-I5.

Toerien, M., Sainsbury, R., Drew, P. and Irvine, A. (2013), Putting personalisation into practice: Work focused interviews in Job Centre Plus, Fournal of Social Policy, 42, 2 : 309-27.

Verhaeghe, P. (20I4), What About Me? The Struggle for Identity in a Market Based Society, Brunswick: Scribe Publications.

Watt, N. (20I5), Iain Duncan Smith returns to cabinet to oversee $\mathcal{E}$ I2 bn welfare cuts, http://www.theguardian.com/politics/20I5/may/Io/iain-duncan-smith-conservativecabinet-david-cameron-welfare-cuts (accessed I3 May 20I5). 
West, K. (2013), The grip of personalisation in adult social care: Between managerial domination and fantasy, Critical Social Policy, 33, 4: 638-57.

White, A. (2013), The secret cuts part two: The ILF, NewStatesman, 6 June, http://www. newstatesman.com/politics/2013/06/secret-cuts-part-two-independent-living-fund (accessed 29 April 20I5).

Witcher, S. (20I4), My Choices: A Vision for Self-directed Support, Glasgow: Glasgow Disability Alliance.

Zarb, G. and Nadash, P. (I994), Cashing in on Independence: Comparing the Costs and Benefits of Cash and Services, London: British Council of Organisations of Disabled People. 